\title{
Anarchy, Preferences, and Robust Political Economy
}

\author{
Brad Taylor* and Eric Crampton ${ }^{\dagger}$
}

\section{ABSTRACT}

We consider the relative robustness of libertarian anarchy and liberal democracy to meddlesome preferences. Specifically, we examine how the liberty of those wishing to engage in externally harmless activities is affected by people who wish to prevent them from doing so. We show that intense, concentrated meddlesome preferences are more likely to produce illiberal law in anarchy; while weak, dispersed meddlesome preferences are more likely to do so in democracy. Using insights from the economics of religion, we argue that anarchy is more likely than democracy to produce small groups with intense meddlesome preferences. Absent government provision of public goods, voluntary groups will emerge to fill the gap. Strict religious groups - 'sects' - are more able to overcome collective action problems and will therefore be more prevalent in an anarchic society. These sects are apt to instil intense meddlesome preferences in their members and have the ability to enforce them: anarchy produces the situation to which it is most fragile. Our argument reveals unresolved questions in the conventional understanding of institutional robustness.

Keywords: Robust Political Economy, Anarcho-capitalism, Economics of Religion, Ideology, Endogenous Preferences.

JEL Codes: D63, D70, H11, K40, P10, Z12

\section{INTRODUCTION}

We should evaluate political systems not only on how they behave under ideal assumptions but also on how they behave when those assumptions fail. John Stuart Mill and, more recently, James M.

Buchanan have both stressed the desirability of considering the worst-case scenario when comparing alternative institutions. Adam Smith's thought, when considered as a whole, is an example of this robust thinking: in Theory of Moral Sentiments, Smith argues that people have significant concern for others while in The Wealth of Nations, he shows that a market order would produce beneficial outcomes even if people were selfish.

The modern variant of 'robust political economy' derives primarily from the work of Buchanan, ${ }^{1}$ who suggests that making worst-case assumptions at the level constitutional choice, even if those assumptions are empirically unfounded, protects against particularly bad outcomes. Like insurance,

*Graduate student, Department of Political Science, University of Canterbury, Private Bag 4800 Christchurch 8140, New Zealand. e-mail: bradrtaylor@gmail.com

${ }^{\dagger}$ Department of Economics, University of Canterbury. e-mail: eric.crampton@canterbury.ac.nz We would like to thank Andrew Farrant and Ed Stringham for useful comments and suggestions.

${ }^{1}$ Especially Brennan \& Buchanan (1981, 2000 [1985], 2001 [1980]). 
this protection normally comes at a cost. If a less robust system performs better under ideal conditions, the suboptimal performance of the robust system in such cases is analogous to an insurance premium.

Robust political economy and worst-case theorizing has enjoyed something of a renaissance of late. David Levy (2002) attempts to add precision to the idea of Buchanan's robust political economy by linking it with J.W. Tukey’s idea of robust statistics. Peter Boettke and various co-authors have published a number of articles using the idea of robustness (Boettke 2000; Boettke et al 2005; Boettke \& Leeson 2004, 2006; Boettke \& López 2002; Leeson et al 2006). Crampton and Farrant (2004) show traditional constitutional political economy to be non-robust to expressive preferences; they later (2006, 2008) argue the normative implications of the Austrian calculation argument are not robust to assumptions of self-interested planners.

We here consider the relative robustness of libertarian anarchy and liberal democracy to meddlesome preferences. In particular, we show how the negative rights of those wishing to engage in externally harmless activities are affected by the introduction of people who wish to prevent them engaging in those activities. This will reveal limitations and unanswered questions in the way robust political economy has been understood by Levy, Boettke, and others. ${ }^{2}$

\section{ANARCHY AND PREFERENCES}

Stringham and Hummel (2008) argue that preferences are important for the performance of orderly anarchy. Prior analyses by both advocates (Friedman 1989; Caplan \& Stringham 2003) and critics (Cowen 1992; Cowen \& Sutter 1999, 2005) of anarcho-capitalism have heeded Stigler’s dictum, leaving preferences to one side and focusing on constraints. Where most work has focused on the mechanics of anarcho-capitalism, Stringham and Hummel argue that a prior shift in popular preferences towards libertarianism would be necessary for a stable and feasible libertarian anarchy. So, where Cowen and Sutter (2005) see the assumed positive coercion payoffs as leading to the breakdown of libertarian anarchy, Stringham and Hummel argue that a shift in preferences away from coercion may be feasible. Institutions change payoffs and preferences change the subjective ranking of payoffs. If there were an ideological constraint against coercion, people would choose not to coerce, even in the face of positive material payoffs. Stringham and Hummel (2008, pp. 7-14) argue that preferences can change over time and point to a number of historical examples.

Stringham and Hummel are, of course, correct. In the limiting case of a world populated by individuals with identical preferences, social choice problems disappear. But, if preferences can

\footnotetext{
${ }^{2}$ For other recent analyses using the idea of robustness see Beaulier \& Subrick (2006); Farrant (2004); Farrant \& Paganelli (2005); Leeson \& Subrick (2006); Subrick (2006); Voigt (2006); Wagner (2006).
} 
become more liberal, they can also become more illberal:.Stringham and Hummel base their argument for anarcho-capitalism on a best-case view of preferences and ideology in which people accept libertarian doctrine and refuse to engage in coercive behaviour. Under these assumptions, anarchy will outperform the minimal state. Considering the worst-case scenario of changing preferences, however, is not straightforward.

Farrant (2004, pp. 449-450) points out that deviations from best-case assumptions are not as clear-cut and one-dimensional as those of statistics. Real people can deviate from assumptions of publicspiritedness or rationality in many ways; consequently, we cannot rate one political system as more robust than another simpliciter. The precise deviations from assumptions need to be specified as it is possible that one system will be more robust to deviation in one direction, but less robust to deviation in another, than the alternative.

For the purposes of this paper, we will place ourselves into the 'sweet spot' identified by Caplan and Stringham (2003) where the network of protection agencies is strong enough to punish rogue agents but not so strong as to be able to form a government-replicating cartel. In this case, libertarian anarchy will be robust to the existence of self-interested knaves: a well-functioning private defence industry will be capable of preventing aggression against property. The libertarianism of libertarian anarchy, however, will be less robust to certain distributions of meddlesome preferences. In an anarchic society, not only the protection of rights, but also the definition of the rights themselves is determined by market forces: if consumers demand illiberal law, that is what they will get.

\section{ILLIBERAL ANARCHY}

\subsection{Markets in Meddlesome Preference Enforcement}

In a well-functioning market for law, for now holding constant relative technical efficiency of enforcement and avoidance, those rights which garner the highest total willingness to pay will be the rights enforced. When preferences are libertarian in the way Stringham and Hummel imagine and also, if Caplan and Stringham's (2003) argument is correct, when preferences are knavish and selfregarding, a free society emerges. But in any actual society, some people will have preferences over things libertarians see as none of their business. If the total willingness to pay to have some activity prohibited exceeds the total willingness to pay to avoid prohibition, the activity will be prohibited regardless of what libertarian political philosophy has to say about it.

Buchanan (2001 [1977], pp. 24-26) points out the differences of opinion on the boundaries of personal rights. Even self-described libertarians disagree at the margin on what the individual has a right to 
do. ${ }^{3}$ Virtually everything we do affects other people in some way, so Mill’s (1859, Ch. 1, Para. 9) principle that 'the only purpose for which power can be rightfully exercised over any member of a civilized community, against his will, is to prevent harm to others' does not get us very far. The harm principle is imprecise without an adequate definition of harm. We cannot even rely on traditional definitions of externality to solve the problem: Pareto-relevant technological externalities are of course defined relative to individual willingness-to-pay (Buchanan and Stubblebine 1962) and here the default rights position is what's at stake. Even if some natural limit of personal sovereignty exists, though it's hard to see how this could be a meaningful proposition, libertarian anarchy would only be libertarian to the degree to which people accept the validity of this limit. Persistent disagreement makes this seem unlikely.

The production of illiberal laws in anarchy would not necessarily be a market failure. The market is good at satisfying preferences, whether or not those preferences are libertarian. If the market is more efficient than government, it is better at producing both public goods and public bads: Cowen and Sutter (1999) show that cooperative efficacy has both social benefits and social costs; Crampton and Farrant $(2006,2008)$ similarly argue that planner 'calculative efficacy' is harmful when planners are self-interested.

It is not difficult to imagine realistic distributions of preferences under which anarchy would produce illiberal laws. If a large majority of the population disliked the idea of people taking drugs and were willing to pay to have their preference satisfied, for example, it is likely that drugs would in effect be banned (Cowen 1992, p. 256). Of course, enforcement is a public good vis-à-vis the anti-drug majority; but if that free-rider problem cannot be solved, neither can many others.

There needn’t be a majority of busybodies for an anarchist society to become illiberal: a minority of zealous anti-smokers could outweigh a smaller minority of smokers if the majority of non-smokers were indifferent to smoking or the rights of smokers. As long as the willingness to pay for the indulgence of meddlesome preferences exceeds the willingness to pay for protection of liberties, an efficient market will produce an illiberal society.

Busybodies could choose to enforce their preferences themselves or, more realistically, hire protection agencies to do so by paying for a 'premium service', as Long (2003) puts it, which includes efforts to prevent undesired behaviour on the part of others. Long is correct that the number willing to pay for this premium service is bound to be less than the number willing to vote for a similar policy. This does not mean there will be less effort devoted to enforcing meddlesome preferences in anarchy as we here count dollar-votes rather than noses. In democracy, only broadly-shared preferences tend to

\footnotetext{
${ }^{3}$ See, for example, Walter Block's (2003) argument on the appropriate application of the non-aggression axiom in lifeboat situations.
} 
affect outcomes. While the number of people willing to enforce meddlesome preferences in anarchy is likely to be less than those willing to vote for such enforcement, those few can have greater effect in anarchy.

How are busybody preferences enforced in anarchy when the objects of unwanted attention can pay for protection against same? Cowen and Sutter (2005) make the case that a cartelized network of protection agencies easily could enforce restrictions against drug use, for example, if cartel agencies' clients found drug use objectionable and the network consequently declared rogue those agencies protecting the rights of drug users. In that case, the cartel has become government. Absent a cartel, enforcement of busybody preferences is more difficult but remains likely.

Consider the case where the dollar-weighted preferences of a busybody minority greatly outweigh the dollar-weighted preferences of the objects of their tender mercies, with all others indifferent.

Busybodies purchase protection, at a premium, from agencies guaranteeing that sanctioned behaviour is punished and that clients of libertine agencies are forbidden from properties under their protection. These agencies form their own network with two-tiered membership: contributor agencies with busybody clients paying a premium, and compliant agencies with indifferent clients willing to be subject to busybody regulation in exchange for subsidized arbitration fees. Busybodies subsidize the indifferent if they agree to exclude libertines. So long as those indifferent see cost savings from busybody subsidies greater than losses from lost transactions with libertines, they'll choose busybodycompliant agencies.

So, if busybody preferences are of sufficient intensity, agencies will have a client-based demand to effectively declare rogue the libertine agencies. Busybody-compliant firms insufficiently vigilant in policing behaviour among their clients lose access to the subsidised arbitration network. Becker's (1971) analysis of discrimination is apposite: where customers are racist, a segregation equilibrium obtains even where firm owners are not racist. Here, libertines suffer discrimination under similar conditions. A first response by libertines will be to cluster with similar types; however, having lost most opportunities for dealings with the indifferent majority, their neighbourhoods would necessarily become increasingly autarkic. Those with the weakest libertine preferences defect to busybodycompliant agencies, further reducing transactions opportunities for libertines, increasing average costs of membership in libertine agencies, and encouraging further defection. While nothing in the process infringes on anyone's rights, it is difficult to view the outcome as libertarian.

\subsection{Meddlesome Preferences under Democracy}

Meddlesome preferences are not a problem unique to settings of market-chosen law; most countries have in place legislation prohibiting drug use and prostitution, for example. Such policies are generally popular despite many analyses suggesting that they cause more harm than they prevent. We 
here discuss how meddlesome preferences become policy under democracy before turning to comparative institutional analysis.

We begin with an ideal-type ${ }^{4}$ democracy: politicians are faithful agents of voters, are not constrained by constitutional limitations, and do not engage in vote trading across issues. At all times, that which commands majority assent then becomes policy. Without vote trading or bargaining, an ideal democracy will produce those laws preferred by a majority or plurality of voters. Under those conditions, meddlesome preferences become policy only if a majority share those preferences: if the median voter is a busybody, policy follows. In cases where a minority of busybodies has greater intensity-weighted numbers than do the libertines that would be subject to regulation, regulation is not enacted regardless of preference intensity on either side so long as the median voter is indifferent to the libertines' activities. An ideal market perfectly represents preference intensity; an ideal democracy completely ignores it.

\subsubsection{Democracy when preference intensity matters}

Real democracies, of course, vary from their ideal representation. First, many aspects of democracy seem designed to allow preference intensity to be given weight, making outcomes closer to those of markets than would otherwise be the case. Wittman $(1989,1995)$ argues that political markets are designed to allow efficient Coasean bargains between legislators as agents of voters. Legislators operate in competitive electoral markets and are brought together in a small numbers situation in which negotiation is cheap. When legislators' constituencies place different values on different policies, there are potential gains from trade that can be realized via logrolling. Wittman goes so far as to argue that political markets are as efficient as economic markets, giving appropriate weight to preference intensity and achieving Kaldor-Hicks efficiency. In that case, busybodies achieve their desired outcome by subsidizing the indifferent majority via support for other pieces of legislation where those indifferent on the meddlesome-preference dimension have stronger preferences.

The argument presented here depends not simply on the idea that political markets are inefficient, but rather that, as compared to economic markets, political markets place proportionately less weight on strong than weak preferences. The degree to which logrolling places weight on preference intensity depends on what, precisely, legislators trade. Even if Wittman is correct that political markets minimize transaction costs and leave no gains from trade unrealized, trade in such markets is limited to political resources.

\footnotetext{
${ }^{4}$ We are using 'ideal' in the Weberian sense: an accentuation of certain aspects of concrete phenomena to create an abstract archetype. By 'ideal market' we mean the textbook version of perfect competition. By 'ideal democracy' we mean unadulterated majority-rule. This should not be taken to have any normative connotation. See Weber (1999).
} 
Vote-trading allows for mutually beneficial trades within the political sphere, but not mutually beneficial trades between the political and non-political spheres. Strong norms and legal penalties against side-payments of non-political resources create high transaction costs between these spheres and thereby limit the extent to which preference intensity is reflected in policy. Logrolling allows a person with a relatively strong preference over one issue and relatively weak preference over another to have a large influence on the former in exchange for a small influence on the latter. If that person has strong preferences over all policies, however, they cannot easily trade non-political resources for extra influence over policy in general. Logrolling, then, gives weight to the intensity of political preferences relative to other political preferences, but not non-political preferences.

This boundary between the political and non-political spheres is not absolute, however. There are two main channels through which a person can shift resources from the non-political to the political budget in a democracy: campaign contributions and lobbying. Taken together, these do seem to have a significant effect on policy outcomes (Potters \& Sloof 1996). While it is impossible to directly measure whether this effect is strong enough to place anything close to perfect weight on preference intensity, there are strong theoretical reasons for doubt.

Campaign contributions can influence policy outcomes in two ways. ${ }^{5}$ When political parties have fixed policy positions, contributors support their preferred party in order to increase its chances of election. When parties have flexible policy positions, contributors buy policy concessions. Since these concessions will move the party's platform away from that preferred by the median voter, the contribution must be used to offset this electoral disadvantage through campaigning. The empirical evidence suggests that the effects of campaign spending on electoral outcomes (Stratmann 2005, pp. 136-141), and campaign contributions on legislative votes (Ansolabehere et al 2003) are modest but real. ${ }^{6}$

Campaign contributions increase the political influence of those with strong preferences somewhat, but at a high cost. Political competition prevents politicians from ignoring the numerically-dominant preferences of voters in order to accept bribes. This is reflected in the fact that the level of

\footnotetext{
${ }^{5}$ Most public choice literature examining distortions in policy caused by lobbying or campaign contributions tend to focus on pecuniary motivations: policies that enrich one group at the expense of the broader public. There is no particular reason that similar analysis would not apply when analyzing the effects of morality-based lobbyists. Just as a steel tariff benefits concentrated steel interests, hurts concentrated manufacturing interests, and does mild harm to the diffused public, so too for legislation enacting meddlesome preferences benefitting busybodies, harming libertines, and perhaps doing mild harm to the diffused public via enforcement costs. Indeed, Yandle (1983) suggests that inefficient policy is most likely to result when the underlying pecuniary case is matched with an appropriate moral veneer.

${ }^{6}$ Stratmann (2005) reviews the theoretical and empirical literature on campaign contributions and political outcomes.
} 
contribution is insignificant compared to the potential gains that would be available to interest groups if money could easily buy policy (Tullock 1972). Campaign contributions are better seen as expressive consumption goods than instrumental attempts at influencing policy (Ansolabehere et al 2003). Lobbying may have greater effect on outcomes than campaign contributions; however, at least in the Hall and Deardorff (2006) model, lobbying works by changing relative priorities among policies viewed positively by legislators rather than by inducing legislators to support legislation opposed by their constituents. Legislators with functional support from interest-groups will be more effective than those without, but laws are ultimately passed on majoritarian grounds.

Olson (1971) argues that groups more able to overcome free-rider problems and lobby the government are more likely to influence policy. Free-riding is easier to overcome in small groups of people with intense preferences. This provides another avenue for intense preferences, particularly those of groups with high cooperative efficacy, to affect policy. Inefficient policies such as trade protectionism and heavy-handed regulation are often blamed on vested interests having disproportionate influence on government through lobbying and campaign contributions. The empirics of public opinion and public policy, however, suggest such policies also are consistent with voter preferences: very few unpopular policies persist (Caplan \& Stringham 2005), and policy is responsive to changes in voter preferences (Althaus 2003, Crampton 2002). While many policies do provide rents to concentrated interest groups, they also tend to enjoy majority support. Public choice considerations do distort policy outcomes, but typically on margins where voters are at worst indifferent. Busybodies seeking the implementation of policy running contrary to median voter preferences will have a difficult time. ${ }^{7}$

3.3 Comparative Institutional Analysis: Meddlesome markets and politics

While there is some scope for preference intensity to affect policy in democracy, the transaction costs of trading political for non-political goods are high; relatively few such trades occur. Legislators get some benefit from bending to the will of interest groups but cannot ignore the will of the majority and expect to stay in office.

Anarchy, on the other hand, produces no budgetary boundary between political and non-political resources: law and private consumption are purchased with a common currency. A person with strong preferences over law can have a disproportionate influence in all issues by forgoing private consumption. The scope for preference intensity to influence law is thereby greater under anarchy than democracy.

\footnotetext{
${ }^{7}$ The 2005 New Zealand elections provide illustration: a religious group’s campaigning on behalf of, and with the tacit approval of, the National Party arguably cost the National Party the election. In a country where atheists outnumber any single religious denomination, voters worried about the quid pro quo.
} 
Arguing that meddlesome preferences can be easier to enforce through the market than democracy appears to contradict Roback’s (1986) insight that discrimination is cheaper at the ballot box than in the marketplace. She shows that legislation rather than consumer demand drove streetcar segregation in the American South under Jim Crowe; streetcar companies did not find it profitable to enforce such a policy voluntarily as there was insufficient effective consumer demand - taste for discrimination for segregation to emerge in the market. In the voting booth, people were unencumbered by the cost of their preferences and those with even the slightest inclination voted for segregation. ${ }^{8}$ As Caplan (2001, 2007) argues, preferences are cheaper to express in the voting booth than the marketplace. This produces race-based discrimination under democracy but not the market when the majority is mildly racist and the minority is strongly non-racist, as Roback shows. If we invert the distribution of preferences, we should expect the opposite result.

In the market for law, the willingness to pay relative to others determines which rules prevail; in democracy, the largely unweighted preferences of voters. When most people are mildly racist, a democracy will produce racist law while a market will not. When most people are mildly anti-racist, a democracy will produce non-racist law. In some such situations, a market will produce racist law. If a majority of voters prefer law A, but B garners more willingness to pay, a democracy will produce A and a market will produce B. This is equally true whether A or B is an illiberal law.

We should expect the market to produce illiberal laws when meddlesome preferences are held strongly by a few individuals. Individuals with idealistically libertarian preferences willing to stand up for the rights of the oppressed minority may counterweight the preferences of busybodies, but worst-case theorizing counsels against relying on this. Majority rule will produce illiberal laws when meddlesome preferences are held weakly by many individuals. Those harmed by illiberal laws, as well as idealistic liberals, will attempt to lobby government for their repeal. Again, the success of such attempts should not be relied upon. If a majority favour a particular law, it will likely prevail.

Suppose an illiberal minority's utility from enforcing an illiberal law exceeds that of an oppressed minority plus a weakly liberal majority from a liberal law. In this situation the unweighted preferences will obviously be in favour of the liberal law. If democracy gives some weight to preference intensity the majority favouring the liberal law will need to be significant. More formally: where $\operatorname{WTP}_{\mathrm{x}}(\mathrm{y})$ is the willingness to pay of group $\mathrm{x}$ for law $\mathrm{y}$ above and beyond implementation and enforcement costs and $\mathrm{N}_{\mathrm{x}}$ is group x's numerical strength.

\footnotetext{
${ }^{8}$ Roback's work here can be viewed as perhaps the nicest historical piece of evidence in favour of Brennan and Lomasky's (1993) model of expressive voting.
} 


$$
\begin{aligned}
& \mathrm{WTP}_{\text {illiberal }}(\text { ban })>\mathrm{WTP}_{\text {oppressed minority }}(\text { allow })+\mathrm{WTP}_{\text {weakly liberal }}(\text { allow }) \\
& \mathrm{N}_{\text {illiberal }}<\mathrm{N}_{\text {oppressed minority }}+\mathrm{N}_{\text {weakly liberal }}
\end{aligned}
$$

In this situation the market produces illiberal law while democracy produces liberal law. This is not a market failure, but libertarians should prefer the democratic outcome. The liberalism of anarchy is more fragile to intense meddlesome preferences, while the liberalism of democracy is more fragile to weak meddlesome preferences.

Of course, it is likely that there are cost differences between enforcing illiberal laws and protecting oneself against those laws. Preventing a person from taking drugs requires constant monitoring and enforcement. To avoid all but the most serious attempts at drug prohibition, a person simply needs to refrain from public use. Even if the illiberal minority had a greater willingness to pay for prohibition than drug users had for toleration, cost differentials could maintain the liberal outcome.

This narrows the range of preferences under which anarchy will produce illiberal law, but does not remove the potential altogether. Illiberal law will prevail when the preference differential between liberal and illiberal law outweighs the cost differential. Further, the cost asymmetry between enforcement and avoidance is not universal as some laws require very little monitoring. A religious group wishing to prevent public statements criticizing its doctrines would not be faced with significant monitoring costs since the very act of making a public statement makes the act apparent to any interested party. ${ }^{9}$

Even if illiberal laws cannot be perfectly enforced, imperfect enforcement can impose significant costs on the oppressed minority and have a substantial effect on behaviour. A group wishing to prevent drug use may find it prohibitively costly to monitor people in their homes, but more manageable to prevent open sale. Making potential customers aware of an offer for sale also informs others. Imperfect enforcement would lead to black markets. If drugs cannot be openly used, sold, and advertised, liberty is thereby reduced. The effect is little different from that of government prohibition. As things stand, the police find it costly to prevent drug use and do not enforce prohibition perfectly.

Moving away from a static comparison, cost innovation in the private sector could make anarchic law more enforceable over time. Market incentives for innovation would enable protection agencies to more efficiently monitor and enforce prohibitions. It is impossible to say whether these incentives

\footnotetext{
${ }^{9}$ The attempts of members of the Church of Scientology to silence critics through threats of legal action and extra-legal intimidation provide an interesting example. Details of legal cases are archived by the Electronic Frontier Foundation at http://eff.org/legal/cases/Scientology_cases/ . Ascalon (1995) outlines other intimidation tactics used by members of the Church.
} 
would increase efficiency enough to match the power of coercive taxation and make illiberal law more enforceable under anarchy than government, but the efficiency advantage of those wishing to protect against such laws will be lost.

\section{ENDOGNOUS BIGOTRY}

Since institutions have cultural effects (Bowles 1998), the robustness of a political system depends not simply on its behaviour under varying conditions, but also on the likelihood of those conditions holding. Farrant (2004, p. 448) sees this as a problem in Levy's analogy between robust political economy and robust statistics. The technique used in statistical analysis does not affect the normality of the data whereas the prevailing political and economic institutions do affect the preferences of individuals.

The link between institutions and preference outcomes is difficult. Cowen (2007) suggests that government is a normal good: people demand more of it as they become wealthier. If anarchism produces more wealth, Cowen's hypothesis suggests that it would also produce more government. Stringham and Hummel (2008, p. 7) speculate that as people get wealthier and more educated, they will become more cultured, accept the humane teachings of libertarianism, and stop believing bad economic arguments for government intervention. If libertarian anarchy makes people richer than democracy, it might be more likely to keep people libertarian.

There is no reason to think that preferences or ideology will be homogenous in an anarchic society; to speak of preferences changing in a liberal or illiberal direction is a simplification. The argument above suggests that a relatively small group with illiberal preferences will be able to have those preferences satisfied if their preferences are sufficiently strong and collective action problems can be overcome. The economics of religion suggests that illiberal preferences and the cooperative efficacy of a group will be positively correlated. Anarchists and other libertarians imagine voluntary organizations stepping in to provide public goods currently provided by the state. If this is true - i.e. if state and voluntary organizations are substitutes - and a significant proportion of voluntary organizations are religious in nature, we should see more meddlesome preferences under anarchy than government.

Churches and other religious organizations can be seen as clubs providing members a variety of quasipublic goods (Buchanan 1965; Iannaccone 1998, pp. 1482-1484). Standard microeconomic theory predicts that as the state provides fewer public goods, the demand for services offered by churches increases.

Hungerman (2005) finds evidence that church and state are substitutes by showing that a reduction in government welfare availability leads to an increase in charitable church activity. Welfare is a public 
good to the extent that people prefer others not live in poverty but would free-ride on the charity of others, and a club good to the degree it serves as social insurance. Government provision of at least one public good, then, crowds out private provision through churches. It seems very likely that this will be true of other public and club goods. In the absence of government, more public goods will be provided by religious organizations.

Not all religious groups are meddlesome. However, Iannaccone $(1988,1992,1994)$ argues that strict churches are more adept at producing club goods. Requiring members to conform to costly behavioural norms weeds out the uncommitted and reduces free-riding. There are positive externalities to other members from participation in church activities and monitoring costs increase with group size. Engaging in costly and apparently wasteful signalling can increase the value of group membership by increasing average participation. Members can also commit to the group by making themselves stigmatized by outsiders, thereby reducing their opportunities outside the group. This suggests a distinction between low-commitment 'churches' and high-commitment 'sects'. While people can belong to churches at lower cost, sects provide more benefits. For Iannaccone, sects are not the product of brainwashing, as is commonly supposed, but second-best solutions to collective action problems.

Sects are better than churches at producing both religious and material club goods such as protection and various other social services. In the absence of government, we should expect to see more sects (Iannaccone \& Berman 2006). Mulholland (2007) finds that hate groups are more likely to form in areas with less public schooling and more crime. ${ }^{10}$ Hate groups provide services such as protection and education while strict norms ensure active participation.

While religious belief, by positing an unquestionable and objective moral order, seems a particularly effective means of binding cult-like clubs together, non-religious sects are also possible. The cases of Islamic terrorism and the various white-supremacist groups in the United States and elsewhere offer striking examples of sects enforcing illiberal standards of conduct and otherwise coercing outsiders.

Berman and Laitin (2008) argue that extremist religious groups such as Hamas, Hezbollah, and the Taliban are particularly adept at producing local public goods. Such groups tend to arise in areas with little government provision of public goods. These groups place strong prohibitions on members and also attempt to enforce their value-systems on outsiders. The requirement for signalling in sects means that these groups are able to recruit and retain members willing to engage in very costly activities, including making suicide attacks.

\footnotetext{
${ }^{10}$ Mulholland is not suggesting that crime results from a lack of government, but that crime reduction is a public good. Hate groups form when there is greater need for the voluntary production of public goods.
} 
While sects do not necessarily attempt to enforce illiberal rules on outsiders, the usual argument against this happening in anarchy is absent. The costliness of monitoring and punishing behaviour deemed undesirable by the cult does not provide a disincentive, since costliness is a necessary part of signalling. Since cults are more cooperatively effective than churches or the general population, they will have fewer problems enforcing whatever preferences they have.

To illustrate, suppose a sect has greater willingness to pay for and derives greater utility from an illiberal law than does the oppressed minority for and from a liberal law. Let us further suppose that the addition of a weakly liberal majority makes the total utility from the liberal law greater than for the illiberal law. Anarchy would produce the liberal law if the costs of cooperation were constant across groups. If the sect has sufficiently greater cooperative efficacy than the liberal majority, however, anarchy will produce illiberal law. The cooperative efficacy of the oppressed minority will normally be irrelevant, since self-protection is a private good.

Using the same notation as above, but with the addition of $C_{x}$ denoting the cooperative efficacy of group $\mathrm{x}$, and $\mathrm{U}_{\mathrm{x}}(\mathrm{y})$ denoting the aggregate utility group $\mathrm{x}$ derives from law $\mathrm{y}$, democracy will produce liberal law and anarchy illiberal law when:

$$
\begin{aligned}
& \mathrm{WTP}_{\mathrm{x}}(\mathrm{y})=f\left(\mathrm{U}_{\mathrm{x}}(\mathrm{y}), \mathrm{N}_{\mathrm{x}}, \mathrm{C}_{\mathrm{x}}\left(\mathrm{N}_{\mathrm{x}}\right)\right) \\
& \mathrm{WTP}_{\text {sect }}(\text { ban })>\mathrm{WTP}_{\text {oppressed minority }}(\text { allow })+\mathrm{WTP}_{\text {weakly liberal }} \text { (allow) } \\
& \mathrm{N}_{\text {sect }}<\mathrm{N}_{\text {oppressed minority }}+\mathrm{N}_{\text {weakly liberal }}
\end{aligned}
$$

This result violates utilitarian criteria when

$$
\begin{aligned}
& \mathrm{U}_{\text {sect }}(\text { ban })>\mathrm{U}_{\text {minority }}(\text { allow) } \\
& \mathrm{U}_{\text {sect }}(\text { ban })<\mathrm{U}_{\text {majority }}(\text { allow })+\mathrm{U}_{\text {minority }}(\text { allow })
\end{aligned}
$$

In anarchy, free-riding means the liberal majority cannot cooperate and provides little or no protection of the minority against the sect. Sect-members have their way. In the case above, we have something of a market failure. Democracy decreases the costs of cooperation for the weakly liberal majority compared to the sect. Since law is positional in either markets or democracies, this produces more liberal law. ${ }^{11}$

\footnotetext{
${ }^{11}$ This may understate the benefit of democracy relative to anarchy. With higher cooperative efficacy, the resources expended on enforcement may also have a greater effect on outcomes.
} 
Borrowing the basic structure from Levy (2002), but adding a third dimension, figures 1-3 represent the comparison graphically. ${ }^{12}$ The horizontal axes represent the proportion of the population with meddlesome preferences and the intensity of those preferences respectively. The vertical axis represents the resulting level of liberty. The shaded plane shows the level of liberty resulting from any combination of proportion and intensity of meddlesome preferences.

The graphs show that neither anarchy nor democracy is more robust to meddlesome preferences in general. Anarchy produces more liberty than government under ideal conditions, i.e. when nobody has meddlesome preferences. The liberalism of anarchy is more robust to dispersed (high proportion, low intensity) meddlesome preferences, while that of democracy is more robust to concentrated (low proportion, high intensity) meddlesome preferences.

In figure 1, representing anarchy, liberty decreases with increases in the proportion of the population with meddlesome preferences but, due to the higher cooperative efficacy of small groups, at a decreasing rate. Liberty decreases with meddlesome preference intensity at an increasing rate due to the higher cooperative efficacy of groups with strong preferences.

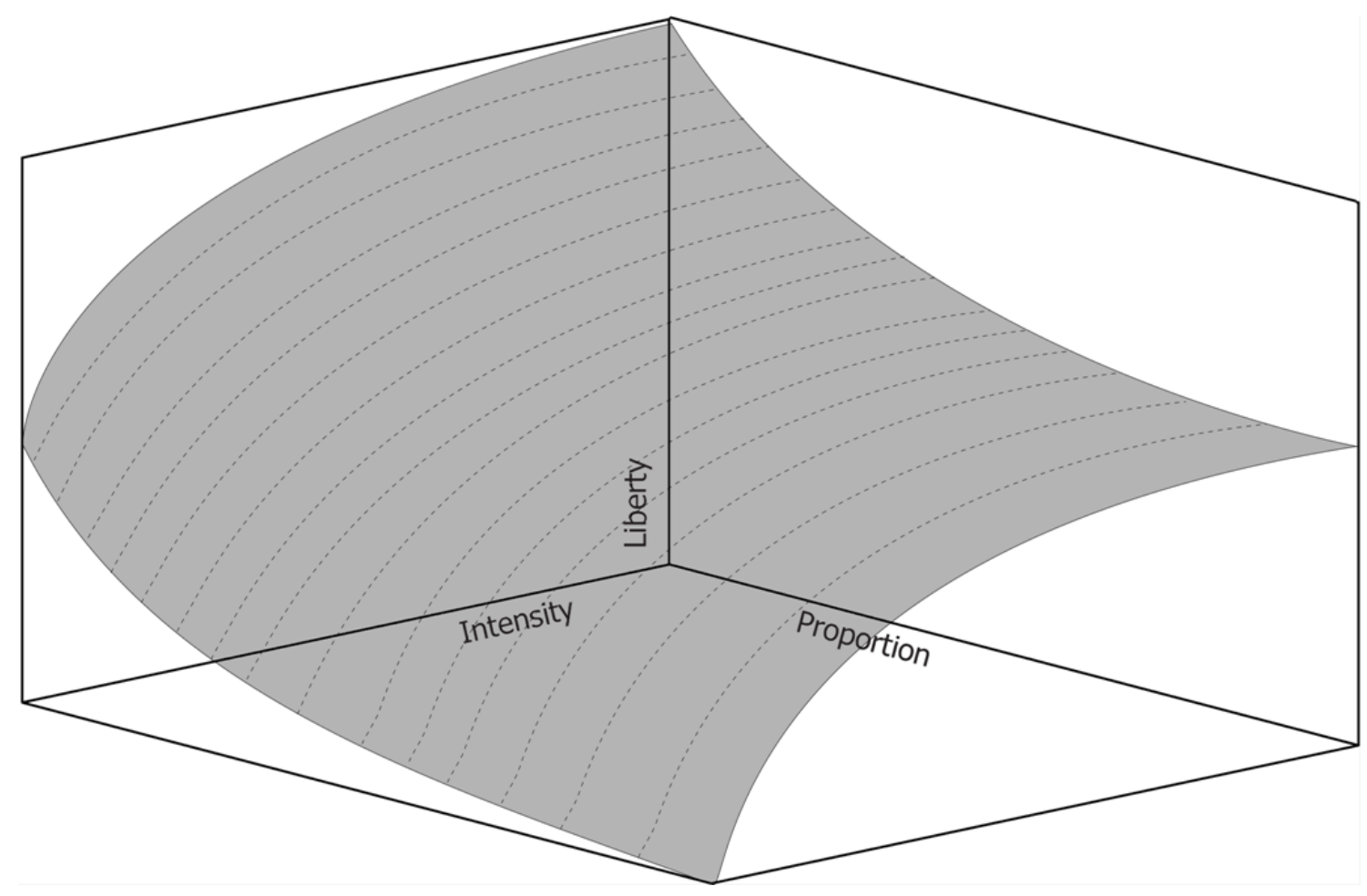

Fig. 1: Liberty and Meddlesome Preferences in Anarchy

\footnotetext{
${ }^{12}$ Crampton and Farrant (2006: 90) make similar use of a three-dimensional graph representing the robustness of a political institution to two interacting variables. The graphs are meant to be illustrative rather than precise. As such, only the general contours are relevant to our argument
} 
In figure 2, representing democracy, liberty remains relatively constant with proportion until slightly less than $50 \%$, before dropping suddenly as the majority becomes meddlesome. Liberty does not fall straight down at 50\%, as it would under ideal-type democracy, since logrolling and the logic of collective action give some weight to preference intensity. This is shown by the mild but increasing slope on the intensity axis. As preferences become very intense, the cooperative efficacy of illiberal groups will increase and they will be more able to lobby government.

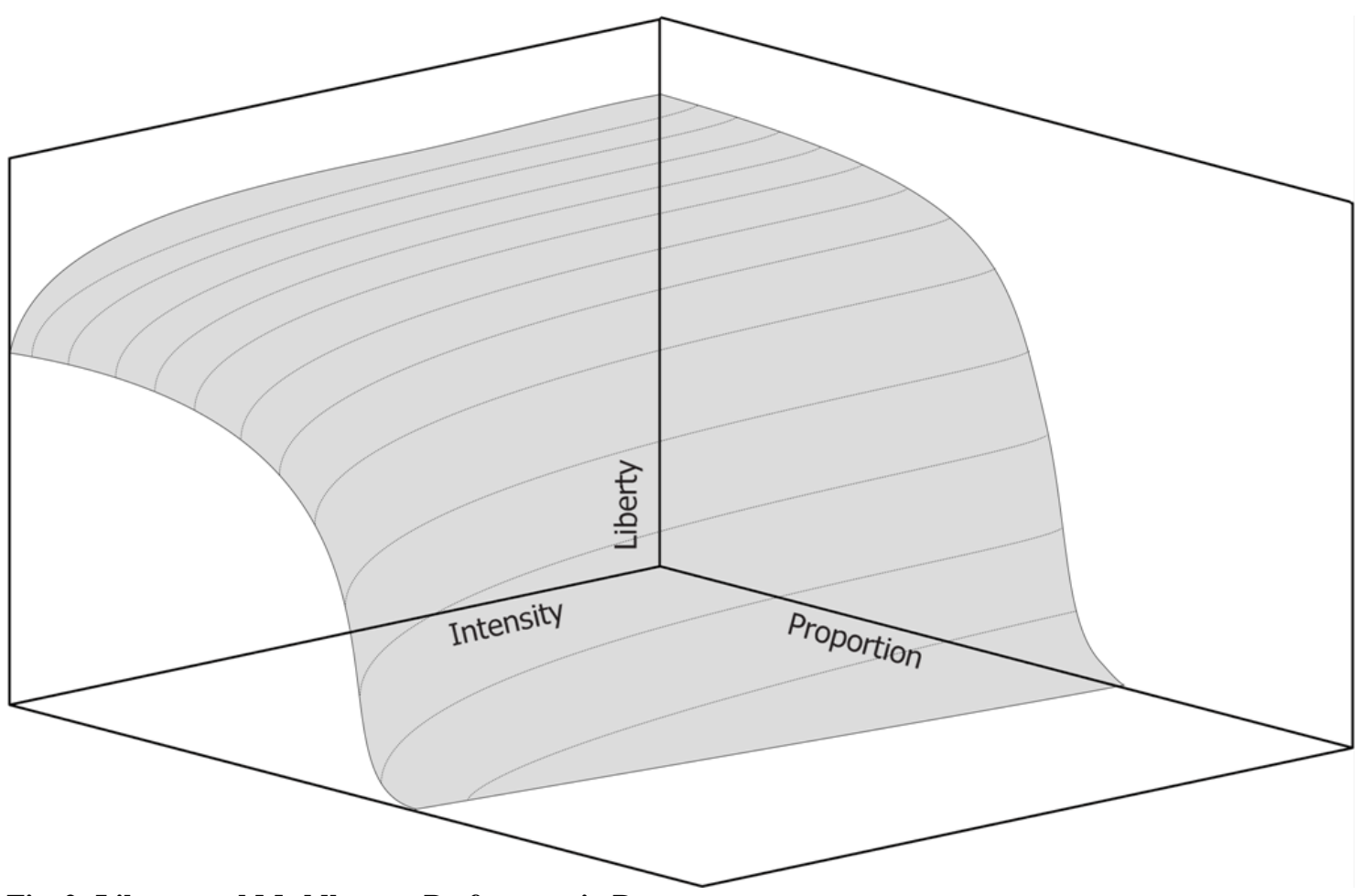

Fig. 2: Liberty and Meddlesome Preferences in Democracy

Figure 3 overlays anarchy and democracy, with the shaded regions showing the plane which produces a higher level of liberty for the corresponding distribution of meddlesome preferences. Democracy, represented by lighter shading, tends to dominate where proportion is low. Anarchy dominates in close to ideal conditions, and also where proportion is high. The vertical distance between the planes is especially pronounced with high proportion and low intensity, where anarchy dominates, and with low proportion and high intensity, where democracy dominates.

As sects grow, they often come to resemble governments in their own right - the Taliban being an obvious example. There is thus a fine line between Cowen and Sutter's cartelization argument against libertarian anarchy and our own. Sects may be another avenue through which anarchy evolves into government - in this case extremely repressive government. 


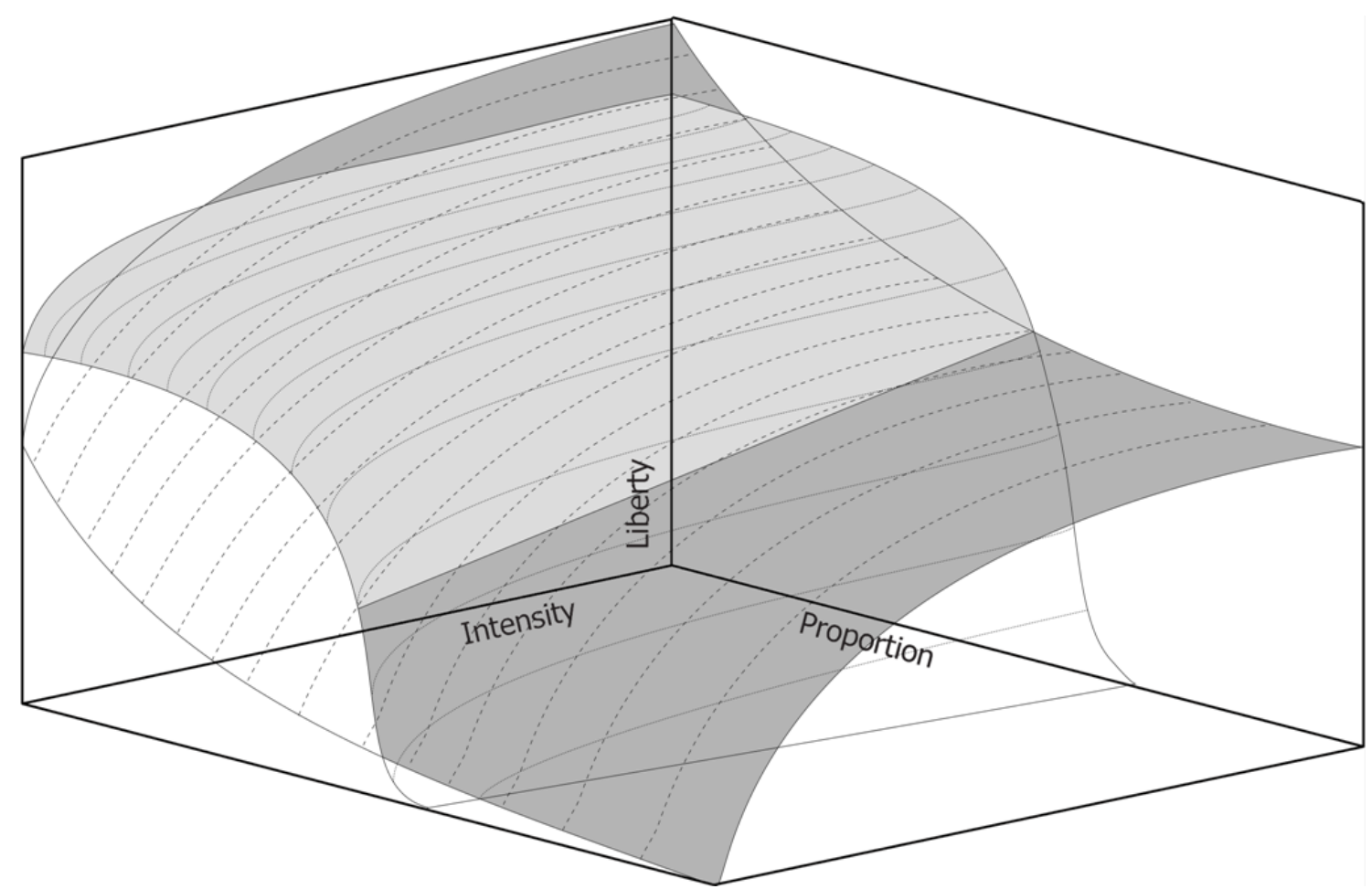

Fig. 3: Anarchy and Democracy Compared

The theory presented here implies that there are cases in which coercive discrimination or enforcement of illiberal norms is possible through non-governmental action, but prevented by government. The search for clear historical examples of democratic politics preventing coercion by sects is complicated by a number of factors. There are no natural experiments in which functional democracies transform into anarchy or vice-versa. In democracies, any coercive behaviour of sects is normally prevented by existing laws, so it is generally impossible to see private coercion dealt-with through the democratic process. ${ }^{13}$ Further, since sects have high cooperative efficacy, they are wellpositioned to influence government as well as take private action.

The activities of the Ku Klux Klan in the United States show that people are willing to go to significant lengths to enforce their preferences, especially when acting as part of a group. While the Klan did make use of local government, individual members also made significant contributions in terms of vigilantism. The group was very cooperatively effective. It was able to coerce people privately through violence and intimidation, and also influence government-made law. The Klan

\footnotetext{
${ }^{13}$ Here, in Bastiat's terms, ignoring the unseen in favour of the seen leads us to underestimate the value of democracy compared to markets.
} 
would likely have continued to exist without government support and, if the sect-state substitution thesis is correct, the group would have been stronger in an anarchic society. ${ }^{14}$

Of more serious recent concern have been radical Islamic sects in Europe, members of which have enforced within-group norms by means of so-called honour killings ${ }^{15}$ (Kurkiala 2003, Bedell 2004, Biehl 2005) and punished external criticism by threat and murder (Smith 2004, Kay 2005).

Democratic governments have there sought to preserve liberal norms against private illiberal enforcement efforts. The fact that members of sects have been willing to take significant costly action even with government opposition, combined with the substitutability of government and sect, is evidence suggesting that we would see more private effort at illiberal norm enforcement in anarchy.

A system of libertarian anarchy seems to help to promote the world-states under which it is least robust to the influence of those with meddlesome preferences. In that state of the world, democracy should be preferred if the relevant dimension for evaluation is freedom from meddlesome impositions. Democracy, by comparison, is least robust to states of the world in which a large proportion of the population holds low-intensity meddlesome preferences. And, worryingly, democracy may well foster low-intensity meddlesome preferences via fiscal externalities: costs of an individual's behaviour that fall on taxpayers because of the operation of a welfare state, public health system, or other social insurance mechanism. While Browning (1999) rather convincingly argues that such externalities are pecuniary rather than technological, as they operate via the budget constraint rather than affecting the utility function directly, such distinctions seem to have little effect on public demand for regulation of activities that have such effects.

We have focused on meddlesome preferences under anarchy, where they previously were assumed to have very little effect; it's rather more obvious that meddlesome preferences are embodied in many kinds of legislation under democracy. We conjecture, though, that democracy may well work to build the kinds of preferences against which it is least robust. Where democracy seems invariably to lead to social insurance, and where social insurance seems invariably to lead to moral hazard problems, it's difficult to avoid the further step to regulations prohibiting demerit goods ${ }^{16}$ that cause fiscal

\footnotetext{
14 The Klan's activities were reduced by the Civil Rights Act of 1871. At first glance, this seems to be a historical example of the argument presented here, with democracy producing liberal law where private action was illiberal. The act, however, was largely the result of Northern legislators and voters enforcing constraints on those in the South. Southern state governments were largely unwilling to pass legislation against the Klan.

${ }^{15}$ A BBC survey (BBC, 2006) found that 10\% of young British Asians believe honour-killings can be justifiable.

${ }^{16}$ Demerit goods are, of course, just fancy talk for things of which folks disapprove. The set of activities causing negative fiscal externalities is very large and includes such elements as drug abuse, smoking (if you discount taxes collected), skydiving, sex, failure to exercise, having low-quality children, not eating enough vegetables, running a car with a badly-tuned engine, not taking your vitamins, playing football, drinking too
} 
externalities. Regulation and taxation of activities causing negative fiscal externalities seems restricted to demerit goods within that set: nobody would think of taxing the man who runs into a burning building to save the terminally ill costly Medicare patient. It seems that fiscal externalities then give voters a reason to demand bans on activities they find distasteful but that they might tolerate if costs were internalized. Both systems seem to give rise to the conditions to which they are least robust, though the dynamics under democracy require further examination.

\section{CONCLUSION}

We have shown that the effect of meddlesome preferences on anarchy and democracy is not straightforward. Anarchy more robustly protects the negative rights of individuals in the presence of widely-held, weak meddlesome preferences; democracy in the presence of concentrated, intense meddlesome preferences. The substitutability of state and sect makes anarchy more likely than democracy to produce small groups with meddlesome preferences and high cooperative efficacy: exactly the situation to which it is least robust.

In cases like these, gustibus est disputandem: taking preferences as exogenous provides a weaker understanding of social change. While political institutions undoubtedly have a large effect on liberty and human welfare, so does ideology. Liberal institutions will not emerge unless people desire them, and preferences influence the operation of the prevailing system (North 1988; Stringham \& Hummel 2008; Hummel 1990, 2001).

Before a comparison between anarchism and the minimal state is politically relevant, preferences would need to shift dramatically in a libertarian direction. Even if anarchism is not desirable with the current distribution of preferences, it may become desirable just as it becomes politically feasible: the desirability and feasibility of anarchy are not independent (Hummel 2001, pp. 533-534). The very preferences that would make libertarian anarchy feasible, however, also lessen its departure from democracy, since law tracks preferences in virtually any political system. ${ }^{17}$

To assume libertarian preferences are stable is best-case thinking, and any political system which requires a specific set of preferences is fragile. Since the conditions under which anarchy is desirable, from a liberal perspective, are not likely to be stable and in any case produce libertarian law under democracy, the libertarian has another reason to be reticent about experimenting with anarchy (Cowen \& Sutter 2005).

much alcohol and not drinking enough alcohol (as moderate consumption seems best for health). The demerit goods are the ones that are taxed, regulated, or forbidden.

${ }^{17}$ Lee (1999) makes a similar argument regarding the minimal state. 
Our argument reveals a number of problems with recent work in robust political economy. Levy’s (2002) amalgamation of various desirable consequences into the generic variable 'good stuff' leads to a neglect of important distinctions: we value many things, and these may be affected differently by the same institution. The judgement of whether one institution is more robust than another presupposes an appraisal of the relative importance of various values. We have shown that under anarchy it is possible for liberty to decrease while welfare in the Kaldor-Hicks sense increases. Libertarians will argue that this is a bad thing, but must do so on philosophical, rather than purely economic, grounds.

The interaction of multiple variables further complicates robust political economy. The effect of meddlesome preferences on the performance of a political system depends on both their prevalence and intensity. Neither anarchy nor democracy is more robust than the other to meddlesome preferences simpliciter, much less more robust in general. As Crampton and Farrant (2006, 2008) show, seemingly unrelated variables can interact to affect the performance of an institution. Individually, planner ignorance and self-interest both affect citizen welfare negatively under socialism. Given self-interested planners, however, deviations from planner omniscience are welfareincreasing.

Further, the deviations from ideal assumptions are not independent of the institution in question. The dynamics of anarchy make sects more likely to form than under democracy, while fiscal externalities may promote busybody regulation in democracy. Simple worst-case theorizing implies the use of a minimax decision rule (von Neumann \& Morgenstern 1964) and does not allow subtle comparison of institutional robustness. It is not only the performance of the system under worst-case assumptions, or even under a range of varyingly bad assumptions, that should be taken as the criterion of robustness, but also the probability of those assumptions holding (Taylor 2008).

Recent works of robust political economy have focused on the knowledge and incentive problems of socialist planners, neglecting the numerous other factors affecting the performance of political economic systems. By focusing on welfare or prosperity, these analyses have not grappled with the problem of exactly what degrades when ideal-assumptions are relaxed.

Most recent work has neglected careful specification of the dependent variable, since a focus on aggregate welfare or economic performance is reasonably straightforward ${ }^{18}$; treated independent variables in isolation; moved unproblematically from consideration of one dependent and one or two independent variables to a conclusion that one institution is more robust than another; and ignored the effect of institutions on independent variables.

\footnotetext{
${ }^{18}$ Wagner (2006) is an exception.
} 
Robust political economy is a more versatile analytical tool than has so far been demonstrated. While it has proved useful in considering the relative merits of socialism and liberalism, as well as unconstrained majority-rule and constitutional democracy, it has much more to offer. To realize this potential, a more careful specification of institutional robustness is required.

\section{REFERENCES}

S. Althaus, Collective preferences in democratic politics, Cambridge University Press, Cambridge (2003).

S. Ansolabehere, J.M. de Figueiredo and J.M. Snyder Jr, Why is there so little money in U.S. politics? Journal of Economic Perspectives 17 (2003), pp. 105-130.

E. Ascalon, Dangerous science: the Church of Scientology's holy war against critics, The American Jurist 9 (1995).

BBC, One in 10 'backs honour killings', BBC News 4 September 2006, available at http://news.bbc.co.uk/2/hi/uk_news/5311244.stm

G. Becker, The Economics of Discrimination (Second edition), University of Chicago Press, Chicago (1971).

G. Bedell, Death before dishonour, The Observer 21 November 2004, available at http://www.guardian.co.uk/world/2004/nov/21/gender.features

E. Berman and D. Laitin, Religion, terrorism and public goods: testing the club model, Journal of Public Economics 92 (2008), pp. 1942-1967.

S. Beaulier and J.R. Subrick, Poverty traps and the robust political economy of development assistance, Review of Austrian Economics 19 (2006), pp. 217-226.

J. Biehl, The death of a Muslim woman, Spiegel Online 2 March 2005, available at http://www.spiegel.de/international/0,1518,344374,00.html

W. Block, The Non-aggression axiom of libertarianism, LewRockwell.com 17 February 2003, available at http://www.lewrockwell.com/block/block26.html

P. Boettke, Towards a history of the theory of socialist planning. In: P. Boettke (ed.) Socialism and the Market: The Socialist Calculation Debate Revisited, Vol. 1: The Natural Economy, Routledge, London (2000), pp. 1-39.

P. Boettke, C. Coyne, P. Leeson and F. Sautet, The new comparative political economy, Review of Austrian Economics 18 (2005), pp. 281-304.

P. Boettke and P. Leeson, Liberalism, socialism, and robust political economy, Journal of Markets and Morality 7(2004), pp. 99-111. 
P. Boettke and P. Leeson, Liberal tolerance as robust political economy, In: G. Moreno-Riano (ed.) Tolerance in the 21st Century: Prospects and Challenges. Lexington Books, Lanham (2006), pp. 201212.

P. Boettke and E. López, Austrian Economics and Public Choice, Review of Austrian Economics, 15 (2002), pp. 111-119.

S. Bowles, Endogenous preferences: The cultural consequences of markets and other economic institutions, Journal of Economic Literature, 36 (1998), pp. 75-111.

G. Brennan and J.M. Buchanan, The normative Purpose of Economic 'science': Rediscovery of an eighteenth century method, International Review of Law and Economics. 1 (1981), pp. 155-166.

G. Brennan and J.M. Buchanan, The Reason of Rules: Constitutional Political Economy, Liberty Fund, Indianapolis (2000 [1985]).

G. Brennan and J.M. Buchanan, The Power to Tax: Analytical Foundations of a Fiscal Constitution, Liberty Fund, Indianapolis (2001 [1980]).

G. Brennan and L. Lomasky, Democracy \& Decision: The pure theory of electoral preference, Cambridge University Press, Cambridge (1993).

E. Browning, The myth of fiscal externalities, Public Finance Review 19 (1999), pp. 3-18.

J.M. Buchanan, An economic theory of clubs, Economica 32 (1965), pp. 1-14.

J.M. Buchanan, A contractarian perspective on anarchy, In: J.M. Buchanan, Choice, Contract and Constraints. Liberty Fund, Indianapolis (2001), pp. 15-27.

J.M. Buchanan and C. Stubblebine, Externality, Economica 29 (1962), pp. 371-384.

B. Caplan, Rational ignorance versus rational irrationality, Kyklos 54 (2001), pp. 3-26.

B. Caplan, The myth of the rational voter, Princeton University Press, Princeton (2007).

B. Caplan and E. Stringham, Networks, law, and the paradox of cooperation, Review of Austrian Economics 16 (2003), pp. 309-326.

B. Caplan and E. Stringham, Mises, Bastiat, public opinion, and Public Choice, Review of Political Economy 17 (2005), pp. $79-105$.

T. Cowen, Law as a public good: the economics of anarchy, Economics and Philosophy 8 (1992) pp. 249-267.

T. Cowen, The paradox of libertarianism, Cato Unbound 11 March 2007, available at http://www.cato-unbound.org/2007/03/11/tyler-cowen/the-paradox-of-libertarianism/

T. Cowen and D. Sutter, The costs of cooperation, Review of Austrian Economics 12 (1999), pp. 161173.

T. Cowen and D. Sutter, Conflict, cooperation and competition in anarchy, Review of Austrian Economics 18 (2005), pp. 109-115. 
E. Crampton, You get what you vote for: electoral determinants of economic freedom, Journal of Private Enterprise 18 (2002), pp. 32-56.

E. Crampton and A. Farrant, Expressive and instrumental voting: the Scylla and Charybdis of constitutional political economy, Constitutional Political Economy 15 (2004), pp. 77-88.

E. Crampton and A. Farrant, Relaxing benevolence: public choice, socialist calculation, and planner self-interest, Review of Austrian Economics 19 (2006), pp. 81-93.

E. Crampton and A. Farrant, Robust analytical egalitarianism: worst-case political economy and the socialist calculation debate, In: S. Peart and D.M. Levy (eds.), The Street Porter and the Philosopher: Conversations on Analytical Egalitarianism. University of Michigan Press, Ann Arbor (2008), pp. 108-131.

A. de Jasay, Is limited government possible? Critical Review 3 (1989), pp. 283-309.

A. Farrant, Robust institutions: the logic of Levy? Review of Austrian Economics 17 (2004), pp. 447451.

A. Farrant and M.P. Paganelli, Are two knaves better than one? Hume, Buchanan, and Musgrave on economics and government, History of Political Economy 37 (2005), pp. 71-90.

D. Friedman, The Machinery of Freedom, Guide to Radical Capitalism,(Second edition), Open Court, La Salle, IL (1989).

R. Hall and A. Deardorff, Lobbying as legislative subsidy, American Political Science Review 100 (2006), pp. 69-84.

R. Holcombe, Government unnecessary but inevitable, Independent Review 8 (2004), pp. 325-42.

J.R. Hummel, National goods versus public goods: defense, disarmament, and free riders, Review of Austrian Economics 4 (1990), pp. 88-122.

J.R. Hummel, The will to be free: The role of ideology in national defense, Independent Review 5 (2001), pp. 523-537.

D. Hungerman, Are church and state substitutes? evidence from the 1996 welfare reform, Journal of Public Economics 89 (2005), pp. 2245-2267.

L. Iannaccone, A formal model of church and sect, American Journal of Sociology 94 (1988), pp. 241-68.

L. Iannaccone, Sacrifice and stigma: reducing free-riding in cults, communes, and other collectives, Journal of Political Economy 100 (1992), pp. 271-291.

L. Iannaccone, Why strict churches are strong, American Journal of Sociology 99 (1994), pp. 11801211.

L. Iannaccone, Introduction to the economics of religion, Journal of Economic Literature 36 (1998), pp. 1465-1496.

L. Iannaccone and E. Berman, Religious extremism: the good, the bad, and the deadly, Public Choice 128 (2006), pp. 109-129. 
I. Kant, Perpetual peace: A philosophical sketch. (M. Smith trans.). G. Allen, London (1903 [1795]).

J. Kay, Censorship through murder, National Post 18 July 2005.

M. Kurkiala, Interpreting honour killings: the story of Fadime Sahindal (1975-2002) in the Swedish press, Anthropology Today 19 (2003), pp. 6-7.

D. Lee, In defense of excessive government, Southern Economic Journal 65(1999), pp. 674-690.

P. Leeson, C. Coyne and P. Boettke, Converting social conflict: focal points and the evolution of cooperation, Review of Austrian Economics 19 (2006), pp. 137-147.

P. Leeson and J.R. Subrick, Robust political economy, Review of Austrian Economics 19 (2006), pp. 107-111.

D. Levy, Robust institutions, Review of Austrian Economics 15 (2002), pp. 131-142.

R. Long, Anarchism as constitutionalism: a Reply to Bidinotto, Strike the Root December 15, 2003. http://www.strike-the-root.com/3/long/long11.html

J.S. Mill, On Liberty (1859),available at http://www.econlib.org/library/Mill/mlLbty.html

S. Mulholland, Safety, stability, and hate group activity, Working paper (2007), available at SSRN: http://ssrn.com/abstract=1004733

D. North, Ideology and political/economic institutions, Cato Journal 8 (1988), pp. 15-28.

M. Olson, The Logic of Collective Action: Public Goods and the Theory of Groups (Second edition), Harvard University Press, Cambridge, Mass. (1971).

J. Potters and R. Sloof, Interest groups: a survey of empirical models that try to assess their influence, European Journal of Political Economy 12 (1996), pp. 403-442.

J. Roback, The political economy of segregation: the case of segregated streetcars, Journal of Economic History 46 (1986), pp. 893-917.

A. Smith, The Theory of Moral Sentiments (1759), available at http://www.econlib.org/library/Smith/smMSCover.html

A. Smith, An Inquiry into the Nature and Causes of the Wealth of Nations (1776), available at http://www.econlib.org/library/Smith/smWN.html

C. Smith, In mourning slain filmmaker, Dutch confront limitations of their tolerance, New York Times 10 November 2004, available at http://www.nytimes.com/2004/11/10/international/europe/10dutch.html

T. Stratmann, Some talk: Money in politics. A (partial) review of the literature, Public Choice 124 (2005), pp. 135-156.

E. Stringham and J.R. Hummel, Is libertarian anarchy feasible? Incentives versus preferences in social change, Paper presented at the Association of Private Enterprise Annual Conference, April 6-8 2008, Las Vegas, available at

http://www.etnpconferences.net/apee/apee2008/PaperSubmissions/Submissions2008/S-2008-130.doc 
J.R. Subrick, Back to the BOG, Austrian-style, Review of Austrian Economics 19 (2006), pp. 95-100.

D. Sutter, Enforcing constitutional constraints, Constitutional Political Economy 8(1997), pp. 139150.

B. Taylor, Robust constitutionalism, Working paper (2008), available at http://bradrtaylor.googlepages.com/RobustConst.pdf

G. Tullock, The purchase of politicians, Western Economic Journal. 10 (1972), pp. 354-355.

G. Tullock, Public Choice: what I hope for the next twenty-five years, Public Choice 77 (1993), pp. 916.

S. Voigt, Robust political economy: the case of antitrust, Review of Austrian Economics 19 (2006), pp. 203-215.

J. von Neumann and O. Morgenstern, Theory of Games and Economic Behaviour (Third edition), John Wiley, New York (1964).

R. Wagner, Retrogressive regime drift within a theory of emergent order, Review of Austrian Economics 19 (2006), pp. 113-123.

M. Weber, The area of economics, economic theory, and the ideal type, (E. Schils and H. Finch trans.) In: M. Weber and R. Swedberg (ed.) Essays in Economic Sociology., Princeton University Press, Princeton (1999), pp. 242-248.

D. Wittman, Why democracies produce efficient results, Journal of Political Economy 97(1989), pp. 1395-1424.

D. Wittman, The Myth of Democratic Failure: Why Political Institutions are Efficient, University of Chicago Press, Chicago (1995).

B. Yandle, Bootleggers and Baptists: the education of a regulatory economist, Regulation 7 (1983), pp. 12-16. 